\title{
Persistence of Welfare Receipt and Unemployment in Germany: Determinants and Duration Dependence
}

\author{
KATRIN HOHMEYER AND TORSTEN LIETZMANN \\ Institute for Employment Research, Regensburger Strasse 104, 90478 Nuremberg, \\ Germany \\ emails: katrin.hohmeyer@iab.de,torsten.lietzmann@iab.de
}

\begin{abstract}
Although the German economy managed the last economic recession comparatively well, it suffers from high and stagnating long-term unemployment and benefit receipt. This article is the first to study the duration and determinants of welfare benefit ("unemployment benefit II") receipt in Germany as a whole, with special attention on duration dependence. The recipients of the means-tested household benefit are not necessarily registered as unemployed, but are, for example, employed with insufficient earnings, in training measures or economically inactive. Due to the heterogeneous situations of welfare recipients, separately studying welfare receipt and unemployment is necessary. By using exceptionally rich administrative data on a $1 \%$ random sample of welfare recipients from between 2005 and 2014, we estimate discrete-time hazard rate models that control for unobserved heterogeneity. The first benefit and unemployment episodes for first welfare recipients between 2006 and $2012(n=26,163)$ are traced monthly until 31 December 2014. Recipients leave unemployment more quickly than welfare. Sociodemographic characteristics, labour market resources and the duration seem to affect both processes. Household composition is less important for leaving unemployment than for leaving welfare. Overall, the results indicate that leaving unemployment and leaving welfare receipt are two different processes that need distinct policies.
\end{abstract}

\section{Introduction}

Fighting long-term unemployment and long-term benefit receipt has been a major policy challenge in recent years in most European countries (e.g. Bentolila and Jansen, 2016; Immervoll, et al, 2015). Long-term unemployment and benefit receipt have negative consequences for individuals and the society (e.g. Blank, 1989; Duell, et al, 2016). Long-term unemployed individuals can suffer from declining human capital, health problems, poverty and social exclusion. For society, long-term unemployment and benefit receipt can endanger the sustainability of health and social protection systems and decrease the matching efficiency in the labour market.

Furthermore, the chances of leaving unemployment and benefit receipt tend to decrease with the duration in this state. Evidence for decreasing chances 
of leaving social assistance (SA) is found, e.g. in the United States (Bane and Ellwood, 1994) and Europe (Bäckman and Bergmark, 2011; Carpentier, et al, 2014; Immervoll, et al, 2015). Two different mechanisms might explain the observed decreasing hazard rates. First, negative duration dependence implies that past benefit receipt might prolong future benefit receipt. This implication could be because, for example, human capital deteriorates during inactivity. Second, sorting mechanisms might imply that benefit recipients with good employment prospects leave welfare receipt comparatively fast, while the recipients with lower (but constant) exit rates stay. Distinguishing between these two sources of persistence is important because the policy implications are different. If the duration of past welfare receipt causes the observed persistence, then policies that prevent individuals from welfare entry might be promising. Additionally, institutional factors such as incentives, stigmatisation and service quality might be particularly important. If, in contrast, the persistence is driven by sorting mechanisms, then directly addressing the obstacles that lead to longterm benefit receipt might be more efficient.

This paper studies the determinants of welfare benefit (Unemployment Benefit II, UBII) and unemployment duration in Germany. Germany is an interesting case because the German economy managed to get comparatively well through the last great economic recession, but it nevertheless suffers from a high and stagnating incidence of long-term unemployment and long-term benefit receipt and increasing poverty rates. The robustness of the German labour market during the crisis is at least partly ascribed to the Hartz reforms in the early 200os, which implied a fundamental change in the system of unemployment benefit and basic income support with the aim of increasing employment (Eichhorst et al, 2010). The Hartz reforms are consistent with the concept of New Welfare in that they involve fighting poverty by moving more people into paid work rather than by income replacement (Bonoli and Natali, 2012; TaylorGooby et al, 2015). Clasen and Clegg (2011) refer to the German welfare reforms as "triple integration" with the dimensions of unemployment benefit homogenisation, risk re-categorisation and activation. The merging of former SA and wage-related unemployment assistance into a new flat-rate means-tested benefit has homogenised benefits. Aiming at preventing poverty, the reforms implied a shift of paradigm away from "Bismarckian" status-protecting benefits towards a more "Beveridgean" model of income support for the people who are not (sufficiently) entitled to unemployment insurance benefits (Bothfeld and Rosenthal, 2018). The broadening of the concept of unemployment means that not only individuals who are registered as unemployed are entitled to the new benefit, but also all individuals who are capable of working and their household members if they have insufficient income to secure a minimal standard of living of the household. Welfare recipients do not have to be registered as unemployed but can be employed, inactive or participating in education or active labour market 
programmes (ALMP). Therefore, benefit recipients also include single parents, low-wage earners or persons with poor health who come into the focus of labour market policies and subject to the activation paradigm. The reforms aimed to activate welfare recipients and strengthen their personal responsibility, with the primary goal of labour market integration (Clasen and Goerne, 2011; Eichhorst, et al, 2010). All benefit recipients have access to measures of support and are required to reduce or end benefit receipt through employment.

Overall, the German welfare system is characterised by broad eligibility criteria and heterogeneous recipients who are not limited to the long-term unemployed. This description is reflected in one of the highest shares internationally of recipients among the working-age population (Immervoll et al, 2015) and should affect the duration and determinants of benefit receipt. First, since unemployment is not a prerequisite of benefit receipt, separately studying the processes of welfare receipt and unemployment is necessary. For the two processes, some mechanisms might be similar, because work is a major route out of welfare receipt. However, work might not be sufficient to leave welfare receipt. Second, because the household is the benefit receiving unit and determines the income threshold to leave benefit receipt, the household context should be an important determinant. Third, the focus on activation and employment warrants a close inspection of the effects of labour market resources and duration dependence for the exits from benefit receipt or unemployment.

Thus far, no study exists concerning the determinants including duration dependence of German welfare benefits after 2005 for the population of recipients. To fill this gap, our study first describes the processes of leaving welfare receipt and unemployment for welfare recipients. Second, it shows how individual and household characteristics determine the chances of leaving welfare receipt and how exit rates develop over the duration of welfare receipt. Third, as welfare receipt and unemployment are two distinct processes, their duration and its determinants are analysed separately. We use exceptionally rich administrative data from the German Federal Employment Agency to estimate discrete-time hazard rate models that control for unobserved heterogeneity for a sample of individuals who entered welfare receipt for the first time between 2006 and 2012. Our results show that the exit rates from unemployment are higher than the exit rates from benefit receipt. Observed - such as labour market resources and the household context - and unobserved heterogeneity are important in both processes. We find a clear indication of duration dependence that seems to be more important for leaving unemployment than for leaving welfare receipt.

The remainder of the paper is organised as follows. Section 2 introduces the German institutional background. Section 3 summarises previous evidence on the determinants of welfare duration and considers relevant determinants in our context. The data and method are described in section 4 , while section 5 presents the results. Section 6 provides a discussion and conclusion. 


\section{Economic and institutional background}

The German economic situation in the past decade has been very specific in the European Union (EU) and has been described as development "From [the] Sick Man of Europe to Economic Superstar" (Dustmann et al, 2014). The unemployment rate in Germany decreased between 2005 and 2014 from 11.2 per cent to 5 per cent, whereas the EU average unemployment rate increased after the Great Economic Recession that started in 2008 until 2013 from 7 per cent to 11.9 per cent (Source: Eurostat). The development of the long-term unemployment rate was similar. Correspondingly, employment rates have been increasing since the early 200os in Germany (Eichhorst and Tobsch, 2015). Although standard (i.e. permanent full-time) employment was the most prominent type of contract in Germany in 2012, the increasing employment rate is mainly driven by the increase in non-standard (e.g. part-time, temporary agency) employment. In contrast, poverty rates and income inequality increased in the 2000 (Haupt and Nollmann, 2014). These developments are partly ascribed to sectoral and occupational changes, the flexibility of the labour market ${ }^{1}$, deregulation and reforms, such as the Hartz reforms (Dustmann et al, 2014; Eichhorst and Tobsch, 2015; Weber, 2015). The Hartz reforms have comprehensively changed the labour market and the system of unemployment benefit and basic income support in Germany since the early 20oos. They came into force in response to recommendations by the OECD (1994) and the European Commission (1999) who advised the national governments to adapt their social protection systems in the direction of more employment-friendly systems to ensure their viability in times of increased job insecurity, changing family structures and an ageing population. In 2005, the last step of the Hartz reforms (Hartz IV) merged the former unemployment assistance and SA to form a new means-tested welfare benefit (UBII, regulated under Social Code II) for needy individuals who are capable of working and their households. As a means-tested flat-rate benefit, the new welfare benefit aims at securing a minimum standard of living (not at status protection). A further goal is decreasing the fiscal burden of unemployment by reducing benefit receipt through faster (re)integration into the labour market. This should be achieved by implementing the principle of rights and duties. On the one hand, benefit recipients are required to make certain efforts to end (or reduce) their benefit receipt (e.g. to accept any job, participate in ALMPs, or actively search for a job). On the other hand, they have certain rights to be assisted to take up employment (e.g. through ALMPs, assistance with the organisation of child care). A wide range of ALMPs for welfare recipients includes training, public job creation (such as One-Euro-Jobs), subsidised employment and placement services (Jacobi and Kluve, 2007). Counselling and monitoring occur and are negotiated between welfare recipients and their case worker. The actions to be taken by the welfare recipients and case worker should be recorded in the individual action plan 
TABLE 1. Labour market states of welfare benefit recipients in 2012 (annual average in 1,000)

\begin{tabular}{lccc}
\hline & $\mathrm{N}$ & In \% of total & $\begin{array}{c}\text { In \% of capable } \\
\text { of working }\end{array}$ \\
\hline Total & 5,917 & 100 & \\
Incapable of working & 1,514 & 25.6 & \\
Capable of working & 4,402 & 74.4 & 100 \\
Registered as unemployed & 1,905 & 32.2 & 43.3 \\
Participating in labour market policies & 476 & 8.0 & 10.8 \\
Employed & 696 & 11.8 & 7.8 \\
In Education & 328 & 5.5 & 6.7 \\
Caring for relatives or children & 296 & 5.0 & 6.5 \\
Temporarily incapable of working & 288 & 4.9 & 5.0 \\
In early retirement & 221 & 3.7 & 4.4 \\
Other & 193 & 3.3 & \\
\hline
\end{tabular}

Source: Department for Statistics of the Federal Employment Agency (2018)

that is signed by both parties. If the welfare recipients do not meet their obligations, their benefits can be cut.

The label "Unemployment Benefit II" is misleading in that not all welfare recipients are registered as unemployed. The benefit is paid to poor households ("Bedarfsgemeinschaften") with at least one member who is capable of working. Compared with basic income support schemes in other countries, being capable of working is defined very broadly, which implies that in the German system, individuals are counted as (unemployed) welfare recipients who might receive incapacity benefits in other countries (Konle-Seidl, 2016). In our observation period, on average between 9.3 to 10.8 per cent of the population that is younger than the legal retirement age received UBII. Of the nearly 6 million recipients in 3.3 million households in 2012, 4.4 million were capable of working (Table 1). All of these welfare recipients are in principle supposed to contribute to reduce the neediness of the household. However, they can be exempted from this requirement if they provide informal care for relatives or care for their children (o.296 million) or participate in general education or vocational training (o.328 million). Other recipients are working with insufficient earnings to live on ( 0.696 million) or participating in ALMPs ( 0.476 million). Approximately $43 \%$ of the recipients who are capable of working ( 1.9 millions) are actually registered as unemployed.

A household is eligible for UBII if its income is insufficient to meet its needs and its wealth remains below the household-specific maximum. The needs are defined by the sum of the standard benefit for each household member and housing costs. In 2018, the standard benefit amounted to $€_{416}$ per month for the head of the household and $€_{374}$ for adult partners. For children, the benefit is from $€_{240}$ to $€_{316}$, depending on their age. The incentives to work can 
therefore be lower for families than for singles. The benefit amount is reduced if household members earn their own income. The reduction rate depends on the gross income of each individual recipient. Benefit recipients can earn $€ 100$ per month without benefit reduction. For monthly earnings between $€_{100}$ and $€_{1,200}\left(€_{1,500}\right.$ for recipients with children) the benefit reduction rate amounts to 80 to 90 per cent. Earnings above $€_{1,200}\left(€_{1,500}\right.$ for recipients with children) reduce entitlements by 100 per cent.

\section{Literature review}

In many countries, welfare benefit recipients often receive benefits for extended and/or repeated periods (e.g. Bane and Ellwood, 1994; Königs, 2018). Two different mechanisms might explain this observed persistence. First, sorting mechanisms imply that benefit recipients with good employment prospects leave welfare receipt comparatively quickly, which leads to an observed decreasing exit rate with the duration of benefit receipt. Second, negative duration dependence implies that the duration of past benefit receipt might prolong future benefit receipt. One major reason for duration dependence is that welfare receipt decreases employment chances (Blank, 1989). Employment chances can decrease because human capital deteriorates during inactivity (Gregory and Jukes, 2001), and unemployment can have negative consequences on (mental) health and employability (Jahoda, 1982). Furthermore, potential employers might regard long-term benefit receipt as a signal for low productivity and might therefore be reluctant to hire long-term benefit recipients (Lockwood, 1991). Moreover, according to expectancy models (Bane and Ellwood, 1994), individuals might lose their motivation to look for a (better) job after being on welfare for a long time. In addition, welfare receipt could affect the household composition (e.g. through divorce and marriage rates) such that future welfare receipt becomes likely (Blank, 1989).

The first empirical studies on the dynamics of welfare receipt originate in the United States (Bane and Ellwood, 1985, 1994). Blank (1989) uses monthly data on the receipt of Aid to Families with Dependent Children (AFDC) by single mothers. After controlling for unobserved heterogeneity, the evidence for duration dependence is only weak. Instead, demographic household characteristics are important determinants of leaving AFDC receipt.

A large project studied SA dynamics in selected European cities in the 1980s and 1990 s but did not find much evidence that the chances of leaving SA decrease with the duration of receipt (Saraceno, 2002).

Several articles address SA dynamics in Scandinavian countries. By studying the first transition of entries into SA receipt in Norway in 1995 to work and self-sufficiency, Dahl and Lorentzen (2003a) find that the effects of the covariates and of time on SA tend to increase after controlling for unobserved 
heterogeneity. They find a positive effect of having children, work experience, and education and a negative effect of age, the national unemployment rate and migration background on the chances of leaving SA receipt. They find no evidence for negative duration dependence during the first year but a steeply increasing exit rate to work. After one year, the exit rate to work decreases slowly, and after four years or more, the hazard rate is still higher than for the first ninety days. Hansen (2009) uses annual administrative data to study the duration of SA receipt and recidivism and finds a bell-shaped pattern of the exit rate in Norway. Furthermore, gender, marital status, children, education, migration status and income are important determinants.

For Sweden, the exit rates are higher for younger and highly educated individuals and are lower for immigrants who recently arrived in Sweden (Bergmark and Bäckman, 2004). In studying SA exits to three exit destinations (any, core workforce and a quick return to SA), Bäckman and Bergmark (2011) find past SA receipt and labour force status to be important for the exits to all three destinations. After controlling for unobserved heterogeneity, past SA receipt is less important for the exits to any destination and to the core workforce, whereas the relative risks to return to SA receipt are inversed from a lower to a higher relative risk for people with past SA receipt compared to people without past SA receipt. Mood (2013) also studies the duration dependence of Swedish SA receipt between 1991 and 2007. Approximately half of the decreasing risk of leaving SA receipt at higher durations is caused by selection. She concludes that duration dependence is "substantively but not dramatically important" (p.120).

Carpentier et al (2014, 2017a, 2017b) use administrative data to study SA exits in Belgium after controlling for unobserved heterogeneity. The exit rates are strongly associated with the characteristics of the benefit recipients (e.g. gender, age, work experience, and citizenship) and the characteristics of the local welfare agency and municipality; the exit rates are less affected by duration dependence (Carpentier et al, 2014). Duration dependence is found for the recipients of Belgian and European origin but not for non-European migrants (Carpentier et $a l, 2017 \mathrm{~b}$ ). The exit to work becomes less likely at longer durations and for repeated time periods (Carpentier et al, 2017a).

The evidence for Germany is limited so far. Several studies examine the SA system before the Hartz reforms. The German cities of Bremen and Halle participated in the previously mentioned European study on SA dynamics (e.g. Leisering and Leibfried, 1999). Longer durations of SA receipt were found for individuals with fewer qualifications and fewer family responsibilities and who have a younger or older age. As previously mentioned, the Hartz IV reform in 2005 dramatically changed the German unemployment and welfare benefit system. Evidence on the dynamics concerning the receipt of the new welfare benefit is limited so far. Household-specific survival rates in welfare receipt 
for the first years after the benefit introduction indicate that couples without children leave welfare benefit receipt faster than couples with children or single parents (Graf and Rudolph, 2009). Thus far, the determinants of welfare benefit duration have been studied only for (single) mothers (Lietzmann, 2017) and adolescent welfare recipients (Schels, 2013) but not for the population of welfare benefit recipients as a whole. ${ }^{2}$ After controlling for unobserved heterogeneity, Schels (2013) does not find evidence for time dependence of exit rates for young adults.

Overall, previous international evidence supports the importance of household characteristics and individual labour market resources for leaving welfare. ${ }^{3}$ Some evidence for duration dependence and the necessity to control for unobserved heterogeneity are found. For Germany, there is so far no evidence on the determinants of leaving welfare und duration dependence for the entire population of welfare recipients that controls for unobserved heterogeneity. Furthermore, previous studies from other countries investigated the role of (un)employment for leaving welfare via control variables or exit routes but did not separately study the unemployment duration for welfare recipients. Our study aims to fill both gaps. As welfare receipt and unemployment are two distinct facts in Germany, we study both processes separately.

Considering the previously discussed arguments and evidence, we expect individual and household characteristics to affect the chances of leaving welfare. More specifically, as eligibility for welfare receipt is defined at the household level, household composition is likely to be relevant. An additional workingage adult as an additional potential earner could increase the chances of leaving welfare, whereas additional dependent household members such as children could decrease the chances of leaving welfare. Furthermore, labour market resources such as qualifications and labour market experience should be positively related to the chances of leaving welfare. Moreover, we expect the previous duration of welfare receipt to be relevant as indicating that the chances to leave welfare decrease with the duration on welfare.

Given that many jobs of welfare recipients are short-term and low-paid, ending individual unemployment by finding a job is often insufficient to exit benefit receipt (Bruckmeier and Hohmeyer, 2018). Therefore, we expect that welfare recipients on average leave unemployment earlier than welfare receipt. The important causes for duration dependence that were described earlier operate via the diminishing employment prospects of the benefit recipients over the time of receipt. Employment prospects as captured by observed labour market resources and duration dependence should be more relevant to the process of leaving unemployment than to benefit receipt. Furthermore, we expect household factors to be relevant but of less importance for leaving individual unemployment than for leaving welfare receipt. 


\section{Data and method}

\subsection{Data}

To analyse the processes of welfare benefit receipt and unemployment, we use rich administrative longitudinal data from the German Federal Employment Agency. The "Sample of integrated welfare benefit biographies" (Stichprobe Integrierte Grundsicherungsbiografien - SIG) is a ten per cent random sample of all UBII recipients between 2005 and 2014. The data contain detailed information about times in welfare receipt and individual and household characteristics. These data are enriched with information on past and current dependent employment, unemployment, job searches and participation in ALMPs from the Integrated Employment Biographies (Antoni et al, 2016).

We use a random 10 per cent sample of the SIG, i.e. a 1 per cent sample of all individuals who receive UBII at least once from 2005 to 2014. To avoid left censoring, we analyse entry cohorts instead of point-in-time or ever-begun samples (Bane and Ellwood, 1994; Dahl and Lorentzen, 2003b). We select individuals who enter benefit receipt between 2006 and 2012 for the first time. Thus, we can observe all individuals for at least two years after the start of their first benefit receipt. The design implies that individuals who entered welfare receipt earlier are observed longer and that only first episodes are observed. We exclude the recipients that start their first welfare receipt in 2005 to avoid the individuals in our sample who very recently received the old SA benefit, which we would not be able to observe due to a lack of national data. Moreover, we restrict our sample to the heads of households and their partners who live in municipalities with complete data between 2005 and $2014 .^{4}$

The data are organised as a monthly person-period record file. We investigate the two processes of welfare receipt and unemployment. Benefit receipt is defined as being a member of a household that receives benefits. Welfare receipt is conditional on insufficient income to secure a minimal standard of living of the household but is not conditional on unemployment. An exit from benefit receipt is recorded if the individual's household does not receive benefits for one month. Unemployment is defined as being registered as unemployed or searching for a job and not being employed. ${ }^{5}$ An unemployment episode starts when individuals become unemployed within the first three months of benefit receipt. ${ }^{6}$ Unemployment ends if an individual is not registered as unemployed in the next month. For welfare recipients, leaving registered unemployment does not have to correspond to starting work, but they can also enter other states (e.g. inactivity or education). Both benefit receipt and unemployment might end without determining the other process to end. Unemployment episodes are right-censored 12 months after the end of benefit receipt. Our final samples include 26,163 individuals with a first welfare episode between 2006 and 2012, and 8,828 individuals who also enter unemployment at the start of their benefit receipt. 


\subsection{Method}

The two processes of benefit receipt and unemployment are modelled separately as discrete-time hazard models. These models estimate the monthly probability to exit benefit receipt or unemployment depending on the duration in the state and time-constant and/or time-varying covariates (Allison, 1982; Jenkins, 2005).

Let $p_{t i}$ denote the probability that individual $i$ has an event during interval $t$, given that no event has occurred before the start of $t$.

$$
p_{t i}=\operatorname{Pr}\left(T_{i}=t \mid T_{i} \geq t, x_{t i}\right),
$$

where $T$ is the discrete random variable that gives the uncensored time of event occurrence. We model the discrete-time hazard function as a logit model with $D_{t i}$ being a step-function of the time intervals to allow a flexible modelling of duration dependence and a covariate vector $x_{t i}$ that includes individual timeconstant and/or time-varying covariates:

$$
\log \left(\frac{p_{t i}}{1-p_{t i}}\right)=\alpha D_{t i}+\beta x_{t i}
$$

As previous research has emphasised the importance of unobserved heterogeneity or frailty (Bäckman and Bergmark, 2011; Blank, 1989; Dahl and Lorentzen, 2003a), we add a normally distributed individual-specific random effect $u_{i} \sim N\left(0, \sigma_{u}^{2}\right)$ that should capture the time-constant unobserved individual characteristics ${ }^{7}$ :

$$
\log \left(\frac{p_{t i}}{1-p_{t i}}\right)=\alpha D_{t i}+\beta x_{t i}+u_{i}
$$

As time-constant covariates we include gender, citizenship, age, end of last dependent employment and labour market experience measured at the entry into benefit receipt. Qualifications, household composition and region of residence are modelled as time-varying covariates. We further control for the year of entry into benefit receipt or unemployment, local labour market conditions and calendar months to capture seasonal variation (for more information on covariates see Table A1.1, Supplementary Materials).

\section{Results}

\subsection{Descriptive results}

Population aggregated survivor (Figure 1) and hazard functions (Figure 2) based on the nonparametric Kaplan-Meier estimators provide descriptive evidence on welfare receipt and unemployment duration (Cleves et al, 2008). The survival function is a cumulative function that describes the probability of still receiving benefits (being unemployed) as a function of time. The hazard function expresses the probability of exit from benefit receipt (or 


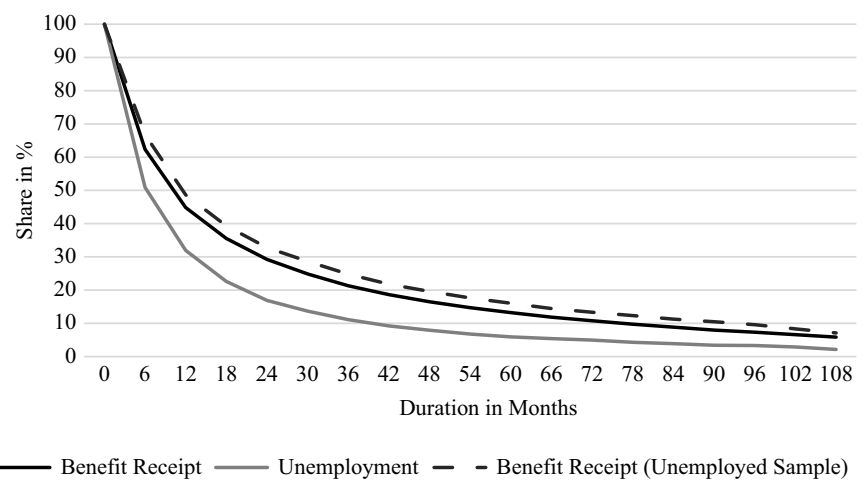

Figure 1. Survival functions in benefit receipt and unemployment

Source: SIG, own calculations. Benefit Receipt (Unemployed Sample): Survivor function in benefit receipt for the subsample of recipients that are also unemployed at entry into benefit receipt
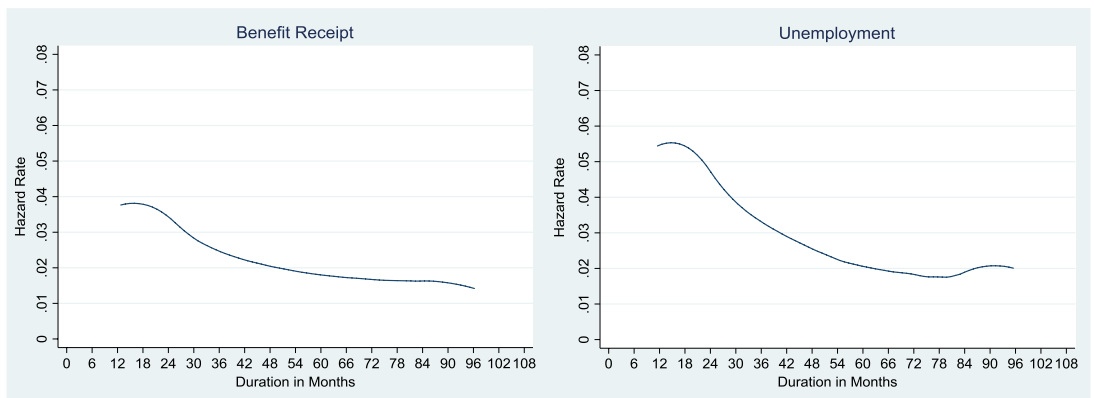

Figure 2. Hazard functions for the exits from benefit receipt and unemployment Source: SIG, own calculations

unemployment) in a given month under the condition that one still received benefits (or was unemployed) in the preceding month.

A large share of welfare recipients leave benefit receipt comparatively quickly. After one year, 55 per cent of the welfare recipients have left benefit receipt (Figure 1). This share is comparable to previous findings (Buhr et al, 2010; Graf and Rudolph, 2009) and is distinctly larger than in point-in-time samples, which found that 44 per cent of welfare recipients in December 2014 already receive benefits for at least four years (Seibert et al., 2017). Nevertheless, our analysis of entry cohorts also reveals a substantial share of long-term benefit receipt with 21 per cent still receiving benefits after 36 months. For unemployed welfare recipients, we find that 32 per cent are still unemployed after twelve months, and 11 per cent after 36 months. As expected, exits from unemployment occur earlier and are not necessarily combined with an exit from benefit receipt. 
Compared to the sample of welfare recipients in general, unemployed welfare recipients are more often single, are younger, were more often never or within the last 12 months employed and have less labour market experience (Table 2). To account for these differences in the sample composition, we also analyse the benefit receipt durations of the subsample of unemployed welfare recipients. The survivor function in benefit receipt of the unemployed sample is much more similar to the survivor function of all benefit recipients than the survival function in unemployment (Figure 1). Thus, leaving unemployment is not the same as leaving welfare receipt and that faster exits are not driven by sample selection but differences in the processes.

These differences between the two processes are also reflected in the population aggregated hazard rates (Figure 2). The hazard rate to exit benefit receipt is stable or slightly increasing in the first year and then decreases afterward. The propensity of leaving welfare decreases with time in this state from approximately 3.5 per cent per month in the first 24 months to under 2 per cent after 48 months. The hazard rate for leaving unemployment is higher than the one for benefit receipt, particularly at the beginning (above 5 per cent) but decreases more steeply in the later stages.

The descriptive statistics of the samples at entry and at month 36 of benefit receipt/unemployment provide a first impression of the reasons for the decreasing hazard rates (Table 2). Individuals with unfavourable characteristics (i.e. older age, foreign citizenship, and less employment experience) are relatively more frequent at the later duration of benefit receipt and unemployment than at entry. Thus, sorting mechanisms might at least partly explain the declining hazard rates.

\subsection{Determinants of welfare receipt duration}

Table 3 shows the marginal effects from the hazard rate models for the process of leaving welfare benefit receipt. The marginal effects indicate the change in the probability to exit welfare receipt in a given month in percentage points compared to the respective reference group while holding the other covariates at their sample means. Model 1 controls only for duration in benefit receipt, whereas model 2 also includes additional covariates. Model 3 additionally includes a normally distributed individual-specific random effect to control for time-constant unobserved heterogeneity.

First, sociodemographic characteristics matter. Women leave welfare receipt slightly slower than men with the same characteristics. The marginal effects for the household composition are as expected, and couples without children or with adult children leave welfare benefit receipt faster than single people. An additional potential earner is associated with higher chances of leaving welfare. In contrast, individuals with children (particularly single parents) leave welfare more slowly. This result might be due to a higher income threshold to 
TABLE 2. Descriptive sample statistics - benefit receipt and unemployment (in \%)

\begin{tabular}{|c|c|c|c|c|}
\hline & \multicolumn{2}{|c|}{ Benefit Receipt } & \multicolumn{2}{|c|}{ Unemployment } \\
\hline & At Entry & Month 36 & At Entry & Month 36 \\
\hline \multicolumn{5}{|l|}{ Sociodemographic Characteristics } \\
\hline \multicolumn{5}{|l|}{ Gender } \\
\hline Male & 51.1 & 46.9 & 53.6 & 58.4 \\
\hline Female & 48.9 & 53.1 & 46.4 & 41.6 \\
\hline \multicolumn{5}{|l|}{ Type of household } \\
\hline Single & 45.7 & 39.4 & 56.7 & $49 \cdot 3$ \\
\hline Couple w/o children & 21.2 & 16.3 & 16.9 & 15.1 \\
\hline Couple w/ adult children & 2.1 & 2.1 & 1.3 & 2.2 \\
\hline Other & 2.9 & 2.9 & 2.3 & 3.4 \\
\hline Couples 1 child & 11.4 & 11.4 & 8.4 & 8.2 \\
\hline Couples 2 children & 6.2 & 9.6 & 5.1 & 10.3 \\
\hline Couples $3+$ children & 2.9 & 4.9 & 2.8 & 3.7 \\
\hline Single parent 1 child & 5.2 & 9.3 & 4.2 & 4.5 \\
\hline Single parent 2 children & 1.8 & 3.2 & 1.7 & 2.2 \\
\hline Single parent $3+$ children & 0.6 & 1.0 & 0.6 & 1.1 \\
\hline \multicolumn{5}{|l|}{ Region } \\
\hline West & 62.9 & 65.4 & 64.8 & 66.4 \\
\hline East & 37.1 & 34.6 & 35.2 & 33.6 \\
\hline \multicolumn{5}{|l|}{ Age in years } \\
\hline Under 25 & 20.0 & 15.3 & 21.3 & 7.5 \\
\hline $25-34$ & 32.0 & 26.3 & 34.5 & 27.6 \\
\hline $35-44$ & 20.3 & 21.6 & 19.4 & 24.1 \\
\hline $45-54$ & 17.1 & 21.7 & 16.5 & 26.1 \\
\hline 55 and older & 10.5 & 15.1 & 8.3 & 14.7 \\
\hline \multicolumn{5}{|l|}{ Citizenship } \\
\hline German & 79.2 & 70.6 & 76.0 & 63.3 \\
\hline Turkish & 5.0 & $7 \cdot 3$ & 4.7 & $5 \cdot 4$ \\
\hline Southern Europe & 4.7 & 5.2 & 4.9 & 4.9 \\
\hline Eastern Europe & 3.7 & $5 \cdot 3$ & 4.9 & 7.7 \\
\hline Northern/Western Europe & 0.7 & 0.7 & 0.9 & 0.8 \\
\hline Africa & 2.0 & 2.9 & 2.2 & 2.8 \\
\hline Asia & 3.7 & 6.7 & 5.2 & 11.4 \\
\hline America/Oceania/Other & 0.7 & 0.7 & 0.9 & 1.3 \\
\hline Unknown & 0.4 & 0.6 & 0.4 & 2.6 \\
\hline \multicolumn{5}{|l|}{ Labour Market Resources } \\
\hline \multicolumn{5}{|l|}{ Qualification } \\
\hline Unknown & 21.6 & 7.1 & 11.7 & 5.0 \\
\hline Low & 17.1 & 19.7 & 16.1 & 17.5 \\
\hline Medium & 54.2 & 67.7 & 59.8 & 66.2 \\
\hline High & 7.1 & 5.5 & 12.3 & 11.2 \\
\hline \multicolumn{5}{|l|}{ Duration since last job ended in months } \\
\hline Never employed & 14.6 & 22.4 & 22.7 & 36.8 \\
\hline Employed at entry & 27.4 & 19.8 & - & - \\
\hline$<12$ & 27.1 & 20.7 & 44.0 & 20.3 \\
\hline $12-23$ & 11.9 & 13.7 & 9.0 & 7.7 \\
\hline $24-35$ & 5.8 & 6.9 & 5.2 & 5.2 \\
\hline $36-47$ & 3.2 & 3.8 & 3.9 & 3.7 \\
\hline $\begin{array}{l}30-4 / \\
\geq 48\end{array}$ & 10.2 & 12.8 & $15 \cdot 3$ & 26.3 \\
\hline Mean labour market exp. in months & 67.1 & 57.5 & 48.0 & 32.2 \\
\hline $\mathrm{N}$ & 26163 & 5151 & 8828 & 536 \\
\hline
\end{tabular}

Source: SIG, own calculations. 
TABLE 3. Estimation results - benefit receipt (marginal effects in percentage points)

\begin{tabular}{|c|c|c|c|}
\hline Model & $\begin{array}{c}1 \\
\text { Basic }\end{array}$ & $\begin{array}{c}2 \\
\text { with } \\
\text { Covariates }\end{array}$ & $\begin{array}{c}3 \\
\text { with Covariates } \\
\text { and Unobs. } \\
\text { Heterogeneity }\end{array}$ \\
\hline \multicolumn{4}{|c|}{ Time in benefit receipt in months (Ref.: 1-3) } \\
\hline $4-6$ & $0.009^{* * *}$ & $0.010^{* * *}$ & $0.014^{* * *}$ \\
\hline $7-9$ & $-0.012^{* * *}$ & $-0.006^{* * *}$ & 0.000 \\
\hline $10-12$ & $-0.022^{* * *}$ & $-0.015^{* * *}$ & $-0.007^{* *}$ \\
\hline $13-15$ & $-0.032^{* * *}$ & $-0.023^{* * *}$ & $-0.015^{* * *}$ \\
\hline $16-18$ & $-0.034^{* * *}$ & $-0.025^{* * *}$ & $-0.016^{* * *}$ \\
\hline $19-21$ & $-0.039^{* * *}$ & $-0.030^{* * *}$ & $-0.022^{* * *}$ \\
\hline $22-24$ & $-0.038^{* * *}$ & $-0.028^{* * *}$ & $-0.018^{* * *}$ \\
\hline $25-30$ & $-0.044^{* * *}$ & $-0.034^{* * *}$ & $-0.025^{* * *}$ \\
\hline $31-36$ & $-0.045^{* * *}$ & $-0.035^{* * *}$ & $-0.025^{* * *}$ \\
\hline $37-42$ & $-0.048^{* * * *}$ & $-0.038^{* * *}$ & $-0.028^{* * *}$ \\
\hline $43-48$ & $-0.050^{* * *}$ & $-0.040^{* * *}$ & $-0.030^{* * *}$ \\
\hline $49-54$ & $-0.052^{* * * *}$ & $-0.041^{* * *}$ & $-0.031^{* * *}$ \\
\hline $55-60$ & $-0.053^{* * *}$ & $-0.042^{* * *}$ & $-0.033^{* * *}$ \\
\hline $61-72$ & $-0.054^{* * * *}$ & $-0.042^{* * *}$ & $-0.032^{* * *}$ \\
\hline $73-84$ & $-0.054^{* * *}$ & $-0.043^{* * *}$ & $-0.032^{* * *}$ \\
\hline $85-108$ & $-0.054^{* * *}$ & $-0.043^{* * *}$ & $-0.031^{* * *}$ \\
\hline \multicolumn{4}{|c|}{ Sociodemographic characteristics } \\
\hline \multicolumn{4}{|c|}{ Gender (Ref.: Male) } \\
\hline Female & & $-0.002^{* * *}$ & $-0.003^{* * *}$ \\
\hline \multicolumn{4}{|c|}{ Type of household (Ref.: Single) } \\
\hline Couple w/o children & & $0.006^{* * *}$ & $0.007^{* * *}$ \\
\hline Couple w/ adult children & & $0.019^{* * *}$ & $0.024^{* * *}$ \\
\hline Other & & $0.005^{* *}$ & $0.006^{* *}$ \\
\hline Couples 1 child & & $-0.003^{* *}$ & $-0.004^{* * *}$ \\
\hline Couples 2 children & & -0.002 & -0.002 \\
\hline Couples $3+$ children & & $-0.011^{* * *}$ & $-0.014^{* * *}$ \\
\hline Single Parent 1 child & & $-0.019^{* * *}$ & $-0.025^{* * *}$ \\
\hline Single Parent 2 children & & $-0.021^{* * *}$ & $-0.027^{* * *}$ \\
\hline Single Parent $3+$ children & & $-0.025^{* * *}$ & $-0.032^{* * *}$ \\
\hline \multicolumn{4}{|l|}{ Region (Ref.: West) } \\
\hline East & & $-0.002^{*}$ & $-0.003^{*}$ \\
\hline \multicolumn{4}{|l|}{ Age in years (Ref.: 25-34) } \\
\hline Under 25 & & $0.003^{* *}$ & $0.004^{* *}$ \\
\hline $35-44$ & & $-0.009^{* * *}$ & $-0.010^{* * *}$ \\
\hline $45-54$ & & $-0.020^{* * *}$ & $-0.024^{* * *}$ \\
\hline 55 and older & & $-0.023^{* * *}$ & $-0.030^{* * *}$ \\
\hline \multicolumn{4}{|l|}{ Citizenship (Ref.: German) } \\
\hline Turkish & & $-0.010^{* * *}$ & $-0.012^{* * *}$ \\
\hline Southern Europe & & -0.001 & -0.002 \\
\hline Eastern Europe & & $-0.010^{* * *}$ & $-0.013^{* * *}$ \\
\hline Northern/Western Europe & & 0.003 & 0.004 \\
\hline Africa & & $-0.009^{* * *}$ & $-0.012^{* * *}$ \\
\hline Asia & & $-0.016^{* * *}$ & $-0.020^{* * *}$ \\
\hline America/Oceania/Other & & -0.003 & -0.004 \\
\hline
\end{tabular}




\begin{tabular}{|c|c|c|c|}
\hline Model & $\begin{array}{c}1 \\
\text { Basic }\end{array}$ & $\begin{array}{c}2 \\
\text { with } \\
\text { Covariates }\end{array}$ & $\begin{array}{c}3 \\
\text { with Covariates } \\
\text { and Unobs. } \\
\text { Heterogeneity }\end{array}$ \\
\hline \multicolumn{4}{|l|}{ Labour Market Resources } \\
\hline \multicolumn{4}{|l|}{ Qualifications (Ref.: Medium) } \\
\hline Unknown & & $-0.002^{*}$ & $-0.003^{*}$ \\
\hline Low & & $-0.006^{* * *}$ & $-0.007^{* * *}$ \\
\hline High & & $0.017^{* * *}$ & $0.022^{* * *}$ \\
\hline \multicolumn{4}{|c|}{ Duration since last job ended in months (Ref.: Never employed) } \\
\hline Employed at entry & & $0.012^{* * 3 *}$ & $0.017^{* * *}$ \\
\hline$<12$ & & $0.009^{* * *}$ & $0.012^{* * *}$ \\
\hline $12-23$ & & -0.002 & -0.002 \\
\hline $24-35$ & & 0.000 & 0.000 \\
\hline $36-47$ & & 0.001 & 0.002 \\
\hline$\geq 48$ & & 0.001 & 0.002 \\
\hline Labour market experience & & $0.000^{* * *}$ & $0.000^{* * *}$ \\
\hline $\begin{array}{l}\text { Labour market experience } \\
\text { squared }\end{array}$ & & 0.000 & -0.000 \\
\hline $\mathrm{N}$ & 512384 & 512384 & 512384 \\
\hline $\mathrm{N}$ (groups) & & & 25727 \\
\hline Log Likelihood & -88025.804 & -86295.493 & -86275.459 \\
\hline $\mathrm{Chi}^{2}$ & 5819.874 & 9280.495 & 5693.962 \\
\hline AIC & 176085.607 & 172750.986 & 172712.917 \\
\hline $\mathrm{BIC}$ & 176275.103 & 173642.732 & 173615.810 \\
\hline Pseudo- $\mathrm{R}^{2}$ & 0.032 & 0.051 & \\
\hline sigma_u & & & 0.481 \\
\hline Rho & & & 0.066 \\
\hline $\mathrm{Chi}^{2}$ for comparison test & & & 40.069 \\
\hline
\end{tabular}

Source: SIG, own calculations.The results are from the discrete-time hazard rate models. As further control variables, models 2 and 3 include years of entry, calendar months and regional labour market types (Rüb and Werner, 2008). For the full results, see Table A1.2 (see Supplementary Materials)

Significance levels: ${ }^{*} 5 \%$; ${ }^{* *} \%$; ${ }^{* * *} 0.1 \%$.

leave benefit receipt or due to time constraints for labour market activities due to child care responsibilities. Furthermore, the region of residence is important; recipients in Eastern Germany have lower chances to leave benefit receipt, which might be due to higher unemployment or lower wage levels. In general, we find an almost linear age effect with lower exit rates in older age groups. The strongest negative determinant of leaving welfare among the sociodemographic characteristics is an age of 55 years or above with a marginal effect of three percentage points. Finally, citizenship affects benefit receipt, with German citizens having the highest exit rates. Although citizens of other northern, western or southern European states do not differ significantly from these German citizens, individuals with Turkish, eastern European, Asian or African citizenship leave benefit receipt significantly more slowly. 
Second, the marginal effects of labour market resources are also as expected. Individuals with better labour market prospects (i.e. individuals who are better qualified, who have recent or current employment experience, and who have more labour market experience) leave welfare receipt faster than people with worse labour market prospects.

Finally, we find that the marginal effects of the time intervals on welfare turn negative after six months in the first two models and after nine months in model 3 after controlling for observed and unobserved heterogeneity. Their absolute values become larger in later intervals. The increase in effect strength decreases after controlling for observed and unobserved heterogeneity, but the basic pattern with considerable negative effects in the later stages of the process remains. We find significant unobserved heterogeneity that should account for the time constant but unobserved characteristics of the recipients such as abilities. The results indicate that parts of the observed duration dependence are driven by (un)observed characteristics. However, other parts seem to be genuine and imply that the future chances of leaving benefit receipt decrease with the time on benefits. These negative effects of time on welfare increase from 0.7 percentage points after ten to twelve months to three percentage points after 37 months and more and remain stable afterwards. The size of the marginal effects at later stages of benefit receipt indicates the importance of benefit duration. A long benefit duration is as detrimental as the most important observable characteristics: namely, age above 55 years and single parenthood.

\subsection{Determinants of unemployment and welfare receipt duration of unemployed welfare recipients}

Table 4 shows the marginal effects for the process of leaving unemployment for welfare recipients. Similar to Table 3, model 1 controls only for duration in unemployment, whereas models 2 and 3 additionally include further covariates and unobserved heterogeneity, respectively. Model 4 represents the marginal effects on leaving welfare for unemployed welfare recipients. The specification is the same as in model 3 in Table 3 but for the subgroup of welfare recipients who also become unemployed when entering welfare receipt. As unemployed welfare recipients are a distinct group of welfare recipients, we regard them separately to trace the differences between leaving welfare and leaving unemployment back to these two distinct processes.

First, we find that women tend to leave unemployment faster than men with the same characteristics. This finding contrasts with the results for the process of leaving welfare receipt, with lower chances of leaving welfare for women in the welfare population sample (Table 3, model 3) and no significant differences between men and women in the unemployed sample (Table 4, model 4). For women, alternative routes to leave unemployment (e.g. inactivity due to family 
TABLE 4. Estimation results - unemployment \& benefit receipt of the unemployed (marginal effects in percentage points)

\begin{tabular}{|c|c|c|c|c|}
\hline Model & $\begin{array}{c}1 \\
\text { Basic }\end{array}$ & $\begin{array}{c}2 \\
\text { with } \\
\text { Covariates }\end{array}$ & $\begin{array}{c}3 \\
\text { with Covariates } \\
\text { and Unobs. } \\
\text { Heterogeneity }\end{array}$ & $\begin{array}{c}4 \\
\text { with Covariates } \\
\text { and Unobs. } \\
\text { Heterogeneity }\end{array}$ \\
\hline Process & \multicolumn{3}{|c|}{ Unemployment } & Benefit Receipt \\
\hline \multicolumn{5}{|c|}{ Time in process in months (Ref.: 1-3) } \\
\hline $4-6$ & $-0.024^{* * *}$ & $-0.016^{* * *}$ & -0.005 & $0.029^{* * *}$ \\
\hline $7-9$ & $-0.043^{* * *}$ & $-0.030^{* * * *}$ & $-0.013^{*}$ & $0.018^{* * *}$ \\
\hline $10-12$ & $-0.048^{* * *}$ & $-0.031^{* * * *}$ & -0.010 & $0.008^{* *}$ \\
\hline $13-15$ & $-0.062^{* * *}$ & $-0.045^{* * *}$ & $-0.023^{* *}$ & 0.002 \\
\hline $16-18$ & $-0.060^{* * *}$ & $-0.041^{* * * *}$ & -0.013 & 0.000 \\
\hline $19-21$ & $-0.067^{* * *}$ & $-0.047^{* * * *}$ & -0.019 & -0.003 \\
\hline $22-24$ & $-0.075^{* * *}$ & $-0.055^{* * * *}$ & $-0.028_{* * * *}^{* *}$ & -0.004 \\
\hline $25-30$ & $-0.081^{\text {**** }}$ & $-0.061^{* * *}$ & $-0.034^{* * *}$ & $-0.011^{* * *}$ \\
\hline $31-36$ & $-0.083^{* * *}$ & $-0.063^{* * *}$ & $-0.034^{* *}$ & $-0.008^{*}$ \\
\hline $37-42$ & $-0.085^{* * *}$ & $-0.064^{* * *}$ & $-0.034^{* *}$ & $-0.009^{*}$ \\
\hline $43-48$ & $-0.092^{* * *}$ & $-0.072^{* * * *}$ & $-0.044^{* * *}$ & $-0.013^{* * *}$ \\
\hline $49-54$ & $-0.092^{* * *}$ & $-0.071^{* * *}$ & $-0.042^{* *}$ & $-0.013^{* *}$ \\
\hline $55-60$ & $-0.096^{* * *}$ & $-0.076^{* * *}$ & $-0.049^{* * *}$ & $-0.015^{* * *}$ \\
\hline $61-72$ & $-0.102^{* * *}$ & $-0.084^{* * *}$ & $-0.063^{* * *}$ & $-0.014^{* * *}$ \\
\hline $73-84$ & $-0.099^{* * *}$ & $-0.081^{* * *}$ & $-0.056^{* * *}$ & $-0.016^{* * *}$ \\
\hline $85-108$ & $-0.093^{* * *}$ & $-0.075^{* * *}$ & -0.038 & $-0.014^{*}$ \\
\hline \multirow{2}{*}{\multicolumn{5}{|c|}{ Sociodemographic characteristics }} \\
\hline & & & & \\
\hline Female & & $0.007^{* * *}$ & $0.009^{* * *}$ & -0.002 \\
\hline \multicolumn{5}{|c|}{ Type of household (Ref.: Single) } \\
\hline Single & & Ref. & Ref. & Ref. \\
\hline Couple & & 0.005 & 0.007 & -0.001 \\
\hline Couple & dren & -0.006 & -0.008 & 0.008 \\
\hline Other & & -0.008 & -0.011 & -0.007 \\
\hline Couple & & -0.004 & -0.005 & $-0.011^{* * *}$ \\
\hline Couple & & $-0.020^{* * *}$ & $-0.027^{* * *}$ & $-0.011^{\text {**** }}$ \\
\hline Couple & & $-0.012^{*}$ & $-0.017^{*}$ & $-0.020^{* * *}$ \\
\hline Single I & & $-0.014^{* *}$ & $-0.018^{* *}$ & $-0.023^{* * *}$ \\
\hline Single I & Iren & $-0.027^{* * *}$ & $-0.036^{* * *}$ & $-0.026^{* * *}$ \\
\hline Single I & ildren & $-0.023^{*}$ & $-0.033^{*}$ & $-0.038^{* * *}$ \\
\hline \multicolumn{5}{|c|}{ Region (Ref.: West) } \\
\hline East & & $-0.007^{*}$ & $-0.010^{*}$ & $-0.006^{* *}$ \\
\hline \multicolumn{5}{|c|}{ Age in years } \\
\hline Under & & $0.016^{* * *}$ & $0.021^{* * *}$ & $0.004^{*}$ \\
\hline $25-34$ & & Ref. & Ref. & Ref. \\
\hline $35-44$ & & $-0.011^{* * * *}$ & $-0.016^{* * *}$ & $-0.010^{* * * *}$ \\
\hline $45-54$ & & $-0.025^{* * *}$ & $-0.034^{* * *}$ & $-0.023^{* * *}$ \\
\hline 55 and & & $-0.031^{* * *}$ & $-0.040^{* * *}$ & $-0.030^{* * *}$ \\
\hline \multicolumn{5}{|c|}{ Citizenship (Ref.: German) } \\
\hline Turkish & & $-0.009^{*}$ & $-0.013^{*}$ & $-0.014^{* * *}$ \\
\hline Souther & & 0.001 & 0.002 & -0.005 \\
\hline Eastern & & $-0.014^{* * *}$ & $-0.020^{* * *}$ & $-0.013^{* * *}$ \\
\hline Northe & urope & -0.003 & -0.005 & 0.001 \\
\hline Africa & & 0.002 & 0.001 & $-0.011^{* *}$ \\
\hline
\end{tabular}


TABLE 4. Continued

\begin{tabular}{|c|c|c|c|}
\hline$\stackrel{1}{\text { Basic }}$ & $\begin{array}{c}2 \\
\text { with } \\
\text { Covariates }\end{array}$ & $\begin{array}{c}3 \\
\text { with Covariates } \\
\text { and Unobs. } \\
\text { Heterogeneity }\end{array}$ & $\begin{array}{c}4 \\
\text { with Covariates } \\
\text { and Unobs. } \\
\text { Heterogeneity }\end{array}$ \\
\hline Asia & $-0.015^{* * *}$ & $-0.023^{* * *}$ & $-0.020^{* * *}$ \\
\hline America/Oceania/ Other & -0.009 & -0.014 & -0.002 \\
\hline \multicolumn{4}{|l|}{ Labour Market Resources } \\
\hline \multicolumn{4}{|l|}{ Qualifications (Ref.: Medium) } \\
\hline Unknown & $-0.008^{* *}$ & $-0.012^{* *}$ & $-0.012^{* * *}$ \\
\hline Low & $-0.007^{* *}$ & $-0.011^{* *}$ & $-0.009^{* * *}$ \\
\hline High & 0.003 & 0.003 & $0.024^{* * *}$ \\
\hline \multicolumn{4}{|c|}{ Duration since last job ended in months (Ref.: Never employed) } \\
\hline Employed at entry & & & 0.003 \\
\hline$<12$ & $0.030^{* * *}$ & $0.042^{* * *}$ & $0.014^{* * *}$ \\
\hline $12-23$ & $0.010^{* *}$ & $0.015^{* *}$ & -0.001 \\
\hline $24-35$ & 0.004 & 0.005 & 0.002 \\
\hline $36-47$ & 0.008 & 0.011 & -0.001 \\
\hline$\geq 48$ & $-0.001 *$ & $-0.001 *$ & 0.001 \\
\hline Labour market experience & $0.000^{*}$ & $0.000^{*}$ & $0.000^{* *}$ \\
\hline Labour market exp. squared & 0.000 & 0.000 & 0.000 \\
\hline $\mathrm{N}$ & 90231 & 90231 & 90231 \\
\hline $\mathrm{N}$ (groups) & & & 8713 \\
\hline Log Likelihood & -23179.685 & -22632.53 & -22621.612 \\
\hline $\mathrm{Chi}^{2}$ & 1434.427 & 2528.736 & 1398.743 \\
\hline Aic & $46393 \cdot 369$ & 45423.06 & 45403.225 \\
\hline $\mathrm{Bic}$ & $46553 \cdot 341$ & 46166.461 & 46156.035 \\
\hline Pseudo- $\mathrm{R}^{2}$ & 0.030 & 0.053 & \\
\hline sigma_u & & & 0.610 \\
\hline Rho & & & 0.102 \\
\hline $\begin{array}{l}\mathrm{Chi}^{2} \text { for } \\
\text { comparison test }\end{array}$ & & & 21.836 \\
\hline
\end{tabular}

Source: SIG, own calculations. The results are from discrete-time hazard rate models. As further control variables, models 2 to 4 include the years of entry, calendar months and regional labour market types (Rüb and Werner, 2008). For the full results, see Table A1.3 (see Supplementary Materials).

Significance levels: ${ }^{*} \%$; ${ }^{* *} 1 \%$; ${ }^{* * *} 0.1 \%$.

obligations) than employment might be more relevant than for men. However, these routes do not necessarily take women out of benefit receipt.

By examining household composition, we find that for the unemployed sample, having a partner for individuals without children is irrelevant not only for leaving unemployment but also for leaving welfare. Furthermore, we find that individuals with children tend to leave unemployment more slowly (except for couples with one child). This finding may be due to child care duties, particularly for women. This negative marginal effect is slightly stronger for single parents (two to three percentage points) than for couples with children (up to around two percentage points). However, the differences are less pronounced 
than for the process of leaving welfare for the welfare sample (Table 3 ). In addition, for the sample of unemployed welfare recipients, couples with children and single parents leave welfare receipt slower than single people (with negative marginal effects of one to two percentage points for couples and two to four percentage points for single parents).

Similar to the process of leaving benefit receipt, we also find negative effects for individuals who live in East Germany and for individuals with citizenship from Turkey, Eastern Europe or Asia. Again, an age of 55 years or older has the strongest negative effect on the exit rate among the sociodemographic characteristics: individuals aged 55 years and above have a 4.0 percentage points lower chance of leaving unemployment in a given month than individuals aged 25 to 34 years.

Furthermore, and consistent with our expectations, stronger labour market resources are associated with a faster exit from unemployment and welfare receipt for unemployed welfare recipients. Individuals who have worked during the previous year show a 4.2 percentage points higher likelihood of leaving unemployment than individuals who have never worked. For individuals whose last job ended one to two years ago, the marginal effect amounts to 1.5 percentage points. However, these effects translate only slightly into higher chances of leaving welfare for individuals in the unemployed sample who have worked within the last year (1.4 percentage points).

Finally, and as expected, we find that the marginal effects of the time intervals in unemployment are negative from the second time interval onwards (after three months). They decrease in absolute terms after controlling for the covariates and unobserved heterogeneity but stay significantly negative for most time intervals. Particularly after two years, unemployment duration is associated with lower chances of ending this state. The marginal effects become stronger with the duration in unemployment and are, at least in the later stages of the process, stronger than for welfare receipt. With a size of approximately six percentage points after five years of unemployment, the effect is considerably larger than the one for individuals with a high age and single parents. This result indicates the existence of duration dependence for unemployment that is more important than for welfare receipt. This finding is not surprising if we consider human capital depreciation as one major reason for duration dependence, which might be more relevant for ending unemployment than for ending welfare receipt, which can also be accompanied by employment.

\section{Discussion and conclusion}

This paper is the first to study the determinants of unemployment and welfare duration and duration dependence for the population of welfare benefit 
(“Unemployment Benefit II") recipients in Germany. Our results show that the chances of leaving welfare are affected by the duration on welfare, household composition and labour market resources. The chances of leaving unemployment are also affected by the unemployment duration and labour market resources but less by household composition. Overall, our results on household composition and labour market resources are qualitatively in line with previous evidence on welfare receipt in other countries, SA in Germany before 2005 and for exits from income poverty (see, e.g. Fouarge and Layte, 2005; Leisering and Leibfried, 1999). One main contribution of this study is the analysis of benefit receipt and unemployment as two different processes. These differ considerably: namely, the exit rates from unemployment are generally higher than the exit rates from benefit receipt. The chances to exit benefit receipt increase during the first six months and then decline almost monotonically afterwards. In contrast, the chances to exit unemployment decrease from the beginning and more steeply when not controlling for unobserved heterogeneity. Controlling for unobserved heterogeneity reduces the importance of the time intervals in both processes but more strongly for unemployment. The higher importance for leaving unemployment is plausible given that these unobserved characteristics could represent abilities not captured by formal qualifications. These unobservable attributes should affect the chances to take up employment and to therefore also end unemployment. Also duration effects are stronger for the process of unemployment: the marginal effects of a long unemployment duration on the exit rate are larger than the ones for most important observable characteristics. For an exit from benefit receipt, taking up employment is not necessarily sufficient since the income and the household composition (that determines the income threshold to leave benefit receipt) is relevant. These results underline the importance to study separately the duration of benefit receipt and unemployment and can be seen as in line with and an individual-level explanation for the finding that new welfare politics seem to be more successful at increasing employment than at reducing poverty at an aggregate level (Taylor-Gooby et al, 2015).

Our results allow several policy recommendations to be derived. First, our results show that the observed declining exit rates from welfare receipt and unemployment are partly driven by sorting mechanisms. Welfare recipients who are better equipped with labour market resources leave unemployment and welfare receipt faster than welfare recipients with fewer labour market resources. Therefore, policies should target these employment obstacles (such as qualifications) and support welfare recipients to improve or adapt their skills. As an age above 54 years is one of the strongest obstacles for leaving unemployment and welfare receipt, policies should particularly target welfare recipients in this age group: for example, by health support measures. Second, significant parts of the observed declining exit rates seem to be driven by genuine duration 
dependence. Thus, policies should intervene early to prevent long-term benefit receipt and long-term unemployment. Third, due to its design, the German welfare benefit system covers heterogeneous groups of recipients. Special support is needed for couples with children and even more so for single parents, who leave welfare receipt slower than single people. Here, labour market policies should be accompanied by policies that improve the possibilities to reconcile work and family. Fourth, as leaving unemployment and leaving welfare receipt are two distinct processes, fighting unemployment alone is insufficient. Labour market policy programmes should not only be targeted towards ending individual unemployment but also at qualified employment with reasonable wages. Activation and work-first policies should be accompanied by investments in recipients' human capital. In addition, measures should contribute to stabilising employment and preventing fast returns to unemployment. A combination of these programmes can possibly improve the long-term financial situation of a household. Accordingly, these policy implications are substantially linked to the specifics of the German benefit system. Its broad eligibility criteria, high incidence and heterogeneous recipients groups make a variety of programmes necessary that can target specific groups with specific problems and focus on either one or both processes of benefit receipt and unemployment. This poses major challenges for case workers. A system with sufficient time, resources and discretion for caseworker to assist benefit recipients seems to be preferable to a fragmented system with different benefits and responsible institutions.

As this article is the first to study duration dependence in welfare receipt and unemployment for welfare benefit recipients in Germany, further research is needed. Given that leaving welfare and leaving unemployment are two distinct processes, future research should investigate more closely the routes out of benefit receipt and their sustainability: that is, the role of employment-related and other exits, multiple repeated episodes and the probabilities of re-entering benefit receipt or unemployment.

\section{Acknowledgements}

We thank Kerstin Bruckmeier and the participants of the ECSR conference 2017, the DGS workshop in Tübingen 2017 and the RC28 summer meeting 2017 for their helpful comments and Ricarda Schomburgk for her assistance. Any remaining errors are ours.

\section{Notes}

1 The nationwide minimum wage did not come into force until 2015.

2 In a related strand of literature and by using dynamic panel models with annual information from survey data, Königs (2014) and Wunder and Riphahn (2014) find some evidence for the existence of genuine state dependence in welfare benefit receipt in Germany. 
3 Research on the dynamics of income poverty also reveals the importance of household composition, labour market resources as well as family and employment related events for leaving poverty (Fouarge and Layte, 2005; Oxley, et al, 2000).

4 When UBII was introduced in 2005, more than three million households with more than six million individuals had to be registered according to the new system with a new software. Therefore, particularly in 2005 , not all municipalities provided complete data. We excluded 186 out of 439 municipalities without complete data in 2005 and 2006.

5 This definition implies that we count ALMP participants as unemployed because they are registered as searching for a job during participation. The only exception is some forms of subsidised employment where the participants are counted as employed in the administrative data while they participate.

6 Individuals can also be registered as unemployed before or without receiving welfare benefits. We restrict our analyses to individuals who start their unemployment and welfare receipt at the same time to avoid left-censoring. This approach implies that we do not look at the unemployed in general but unemployed welfare recipients.

7 Different specifications of the unobserved heterogeneity as a gamma distributed error term (Jenkins, 2004a) and a discrete mixture distribution (Jenkins, 2004b) yield similar results.

\section{Supplementary material}

To view supplementary material for this article, please visit https://doi.org/10. 1017/So047279419000242.

\section{References}

Allison, P.D. (1982), 'Discrete-Time Methods for the Analysis of Event Histories', Sociological Methodology, 13, 61-98.

Antoni, M., Ganzer, A. and vom Berge, P. (2016), Sample of integrated labour market biographies (SIAB) 1975-2014, FDZ-Datenreport, 04/2016 (en), Nuremberg: IAB.

Bäckman, O. and Bergmark, A. (2011), 'Escaping welfare? Social assistance dynamics in Sweden', Journal of European Social Policy, 21: 5, 486-500.

Bane, M.J. and Ellwood, D.T. (1985), The Dynamics of Dependence: The Routes to SelfSufficiency, Report to the U.S. Department of Health and Human Services, Cambridge, Mass.: Urban Systems Research and Engineering.

Bane, M.J. and Ellwood, D.T. (1994), Welfare Realities - From Rethoric to Reform, Cambridge, London: Harvard University Press.

Bentolila, S. and Jansen, M. (2016), Long-Term Unemployment After the Great Recession: Causes and remedies, VoxEU.org, London: CEPR Press.

Bergmark, A. and Bäckman, O. (2004), 'Stuck in Welfare? Long-term Social Assistance Recipiency in Sweden', European Sociological Review, 20: 5, 425-443.

Blank, R.M. (1989), 'Analyzing the Length of Welfare Spells', Journal of Public Economics, 39, 245-273.

Bonoli, G. and Natali, D. (2012), The Politics of the New Welfare State, Oxford: Oxford University Press.

Bothfeld, S. and Rosenthal, P. (2018), 'The End of Social Security as we know it- The Erosion of Status Protection in German Labour Market Policy', Journal of Social Policy, 47: 2, 275-294.

Bruckmeier, K. and Hohmeyer, K. (2018), Arbeitsaufnahmen von ArbeitslosengeldII-Empfängern: Nachhaltige Integration bleibt schwierig, IAB-Kurzbericht 02/2018, Nuremberg: IAB. 
Buhr, P., Lietzmann, T. and Voges, W. (2010), 'Lange Wege aus Hartz IV? Zur Dynamik von Mindestsicherung unter dem Bundessozialhilfegesetz und dem SGB II', ZeS Report, 15: 1, $1-6$.

Carpentier, S., Neels, K. and Van den Bosch, K. (2014), 'How Do Exit Rates from Social Assistance Benefit in Belgium Vary with Individual and Local Agency Characteristics?', Research in Labor Economics: Safety Nets and Benefit Dependence, 39, 151-187.

Carpentier, S., Neels, K. and Van den Bosch, K. (2017a), 'Exit from and re-entry into social assistance benefit in Belgium among people with migration background and the nativeborn', International Journal of Social Welfare, 26: 4, 366-383.

Carpentier, S., Neels, K. and Van den Bosch, K. (2017b), 'Do First- and Second-Generation Migrants Stay Longer in Social Assistance Than Natives in Belgium?', Journal of International Migration and Integration, 18: 4, 1167-1190.

Clasen, J. and Clegg, D. (2011), 'Unemployment protection and labour market change in Europe: towards "triple integration"?', in J. Clasen, and D. Clegg (eds.), Regulating the Risk of Unemployment - National adaptations to post-industrial labour markets in Europe, Oxford: Oxford University Press.

Clasen, J. and Goerne, A. (2011), 'Exit Bismarck, Enter Dualism? Assessing Contemporary German Labour Market Policy', Journal of Social Policy, 40: 4, 795-810.

Cleves, M., Gutierrez, R.G., Gould, W. and Marchenko, Y. (2008), An introduction to survival analysis using stata, College Station, Texas: Stata Press.

Dahl, E. and Lorentzen, T. (2003a), 'Explaining Exit to Work among Social Assistance Recipients in Norway: Heterogeneity or Dependency?', European Sociological Review, 19: 5, 519-536.

Dahl, E. and Lorentzen, T. (2003b), 'Dynamics of social assistance: the Norwegian experience in comparative perspective', International Journal of Social Welfare, 12, 289-301.

Department for Statistics of the Federal Employment Agency (2018), Strukturen der Grundsicherung SGB II (Monats- und Jahreszahlen ab 2005), Juni 2018, Nuremberg.

Duell, N., Thurau, L. and Vetter, T. (2016), Long-term Unemployment in the EU: Trends and Policies, Gütersloh: Bertelsmann Stiftung.

Dustmann, C., Fitzenberger, B., Schönberg, U. and Spitz-Oener, A. (2014), 'From Sick Man of Europe to Economic Superstar: Germany's Resurgent Economy', Journal of Economic Perspectives, 28: 1, 167-188.

Eichhorst, W., Grienberger-Zingerle, M. and Konle-Seidl, R. (2010), 'Activating Labor Market and Social Policies in Germany: From Status Protection to Basic Income Support', German Policy Studies, 6: 1, 65-105.

Eichhorst, W. and Tobsch, V. (2015), 'Not so standard anymore? Employment duality in Germany', Journal for Labour Market Research, 48: 2, 81-95.

Fouarge, D. and Layte, R. (2005), 'Welfare Regimes and Poverty Dynamics: The Duration and Recurrence of Poverty Spells in Europe', Journal of Social Policy, 34: 4, 407-426.

Graf, T. and Rudolph, H. (2009), Dynamik im SGB II 2005-2007- Viele Bedarfsgemeinschaften bleiben lange bedürftig, IAB Kurzbericht 5/2009, Nuremberg: IAB.

Gregory, M. and Jukes, R. (2001), 'Unemployment and Subsequent Earnings: Estimating Scarring Among British Men 1984-94', The Economic Journal, 111, 607-625.

Hansen, H.-T. (2009), 'The Dynamics of Social Assistance Recipiency: Empirical Evidence from Norway', European Sociological Review, 25: 2, 215-231.

Haupt, A. and Nollmann, G. (2014), 'Warum werden immer mehr Haushalte von Armut gefährdet?', Kölner Zeitschrift für Soziologie und Sozialpsychologie, 66, 603-627.

Immervoll, H., Jenkins, S.P. and Königs, S. (2015), Are Recipients of Social Assistance 'Benefit Dependent'? Concepts, Measurement and Results for Selected Countries, IZA Discussion Paper 8786, Bonn: IZA.

Jacobi, L. and Kluve, J. (2007), 'Before and After the Hartz Reforms: The Performance of Active Labour Market Policy in Germany', Zeitschrift für Arbeitsmarktforschung, 40: 1, 45-64. 
Jahoda, M. (1982), Employment and Unemployment - a social-psychological analysis, Cambridge: Cambridge University Press.

Jenkins, S.P. (2004a), PGMHAZ8: Stata module to estimate discrete time (grouped data) proportional hazards models, Statistical Software Components S438501: Boston College Department of Economics.

Jenkins, S.P. (2004b), HSHAZ: Stata module to estimate discrete time (grouped data) proportional hazards models, Statistical Software Components S444601: Boston College Department of Economics.

Jenkins, S.P. (2005), Survival Analysis. Unpublished manuscript, https://www.iser.essex.ac.uk/ files/teaching/stephenj/ec968/pdfs/ec968lnotesv6.pdf.

Königs, S. (2014), 'State Dependence in Social Assistance Benefit Receipt in Germany Before and After the Hartz Reforms', Research in Labor Economics: Saftey Nets and Benefit Dependence, 39, 107-150.

Königs, S. (2018), 'Micro-level dynamics of social assistance receipt: Evidence from four European countries', International Journal of Social Welfare, 27: 2, 146-156.

Konle-Seidl, R. (2016), Integration arbeitsmarktferner Personen im Ländervergleich: Kein Patentrezept in Sicht, IAB-Kurzbericht 01/2016, Nuremberg: IAB.

Leisering, L. and Leibfried, S. (1999), Time and Poverty in Western Welfare States - United Germany in Perspective, New York: Cambridge University Press.

Lietzmann, T. (2017), 'The Contribution of Mothers Employment on Their Family s Chances of Ending Welfare Benefit Receipt in Germany. Analysis of a Two-Stage Process', Sociological research online, 22: 2

Lockwood, B. (1991), 'Information Externalities in the Labour Market and the Duration of Unemployment', The Review of Economic Studies, 58: 4, 733-753.

Mood, C. (2013), 'Social Assistance dynamics in Sweden: Duration dependence and heterogeneity', Social Science Research, 42, 120-139.

Oxley, H., Dang, T.T. and Antolín, P. (2000), 'Poverty Dynamics in Six OECD Countries', OECD Economic Studies, 30: 1, 2000.

Rüb, F. and Werner, D. (2008), “'Den Arbeitsmarkt" gibt es nicht - Arbeitsmarktregionen des SGB II im Vergleich', Jahrbuch für Regionalwissenschaft, 28: 2, 93-108.

Saraceno, C. (2002), Social assistance dynamics in Europe. National and local poverty regimes, Bristol: The Policy Press.

Schels, B. (2013), 'Persistence or transition: young adults and social benefits in Germany', Journal of Youth Studies, 16: 7, 881-90o.

Seibert, H., Wurdack, A., Bruckmeier, K., Graf, T. and Lietzmann, T. (2017), Typische Verlaufsmuster beim Grundsicherungsbezug - Für einige Dauerzustand, für andere nur eine Episode, IAB Kurzbericht 4/2017, Nuremberg: IAB.

Taylor-Gooby, P., Gumy, J.M. and Otto, A. (2015), 'Can 'New Welfare' Address Poverty through More and Better Jobs?', Journal of Social Policy, 44: 1, 83-104.

Weber, E. (2015), 'The Labour Market in Germany: Reforms, Recession and Robustness', De Economist, 163: 4, 461-472.

Wunder, C. and Riphahn, R.T. (2014), 'The dynamics of welfare entry and exit amongst natives and immigrants', Oxford Economic Papers, 66, 580-604. 